\title{
EVALUASI DAN EFEKTIVITAS PROGRAM BAZNAS DALAM PEMBERDAYAAN UMKM DI ERA COVID-19 (STUDI KASUS BAZNAS DI PROVINSI JAMBI)
}

\author{
Yunie Rahayu ${ }^{1}$ \\ Dosen Universitas Muhammadiyah Jambi \\ Ahmad Soleh ${ }^{2}$ \\ Dosen Universitas Muhammadiyah Jambi \\ Prima Audia Daniel ${ }^{3}$ \\ Dosen Universitas Muhammadiyah Jambi
}

\begin{abstract}
ABSTRAK
Ditengah kondisi pademi Covid-19 tanpa terkecuali seluruh sektor dalam perekonomian terdampak. Lebih dari 70 persen pelaku UMKM terancam gulung tikar dan bahkan mati. Melihat kondisi tersebut BAZNAS turut ambil bagian dalam penangan dampak Covid-19 dalam bidang pemberdayaan ekonomi. Namun pelaksanaannya seringkali masih kurang tepat sasaran, baik dalam pemberian bantuan, proses pelaksanaan dan pendampingannya Fokus penelitian ini adalah membahas gambaran program kerja, tingkat efektivitas dan strategi kebijakan yang terpat dalam pemberdayaan UMKM yang dilakukan BAZNAS di Provinsi Jambi. Penelitian ini menggunakan metode desriptif kualitatif dan kuantatif dengan menggunakan data primer dan data sekunder. Penentuan sampel untuk data primer dilakukan dengan pendekatan purposive dan snowball sampling. Ruang lingkup penelitian ini dilakukan pada BAZNAS dan UMKM yang berdomisili di Provinsi Jambi dengan objek penelitian lembaga BAZNAS dan para pengusaha UMKM yang menjadi objek penyaluran bantuan program pemberdayaan sehingga terpetakan dua permasalahan yang saling terkait satu sama lainnya.

Alat analisis yang digunakan dalam penelitian ini adalah: untuk megetahui gambaran program BAZNAS digunakan pendekatan deskritif, kemudian untuk melihat tingkat efektivitas program BAZNAS dalam pemberdayaan UMKM digunakan model Zakat Core Principles (ZCP) dan untuk membuat strategi kebijakan dalam pemberdayaan UMKM digunakan model analisis SWOT.
\end{abstract}

Kata kunci: Evaluasi, efektivitas, Pemberdayaan UMKM

\section{PENDAHULUAN}

Dalam ajaran islam kehidupan dipandang sebagai satu sistem yang saling terpadu selaras, seimbang dan saling terkait antara satu dengan lainnya. Islam memandang kehidupan ini sebagai wujud kasih sayang, tolong menolong dan bersaudara dalam batas azaz yang jelas baik bagi umat islam maupun pada seluruh umat manusia. Sebagai implikasi dari kesetiakawanan sosial tersebut perlu adanya jaminan sosial bagi kaum lemah yang di implementasi dalam bentuk zakat, infaq atau shadaqah.

Esensi dari zakat, infak dan shadaqah bukan hanya sebatas materi yang dikeluarkan lalu kemidian disalurkan untuk mengurangi ketimpangan yang terjadi tetapi lebih pada peran 
sebagai penggerak roda perekonomian. Atas dasar pemikiran tersebut maka negara, organisasi, persyarikatan dan perkumpulan muslim lainnya saling berlomba membentuk organisasi pengelola zakat, infaq dan shadaqah tidak terkecuali negara Indonesia. Perkembangan pengelolaan zakat di Indonesia diawali dengan ditetapkannya UU No.38 tahun 1999 yang selanjutnya direvisi menjadi UU No.23 tahun 2011, dengan tujuan memoderenisasi dan memaksimalisasi pengelolaan zakat serta control terhadap lembaga zakat yang tidak professional.

Tidak terkecuali juga Badan Amil Zakat Infak dan Shadaqah (BAZNAS). Melalui Baznas konsep keseimbangan dalam ajaran islam dapat dilaksanakan dengan baik. Implementasi dari konsep keseimbangan tersebut dilakukan melalui pemberdayaan atau usaha meningkatkan kesejahteraan. Pemberdayaan ini dimaksud sebagai upaya untuk meningkatkan harkat dan martabat masyarakat dari kondisi tidak baik menjadi yang lebih baik.

Dalam kondisi yang tidak menentu seperti saat ini akibat wabah Covid-19 tentu memberi pukulan yang lebih besar bagi perekonomian tidak terkecuali pada sektor UMKM. Banyak pelaku usaha mikro, kecil, dan menengah (UMKM) kelimpungan menghadapi bisnisnya yang terhambat bahkan terancam gulung tikar. Ditambah lagi dengan kebijakan pemerintah yang menerapkan Pembatasan Sosial Berskala Besar (PSBB), sehingga mematikan berbagai aktivitas bisnis pelaku UMKM. Jika hal ini terus berlangsung tidak mustahil aktivitas usaha UMKM akan mati suri angka kemiskinan dan pengangguran akan semakin tinggi dan menjadi beban sosial pemerintah.

Dengan memandang urgensi dan kontribusi UMKM terhadap pembangunan ekonomi bangsa, maka Persyarikatan Muhammadiyah turut berperan serta dalam pemberdayaan UMKM yang diimplementasi melalui Badan Zakat Infaq dan Shadaqah (BAZNAS). Salah satu bentuk konkrit dari program BAZNAS dalam pengembangan UMKM adalah dengan memberikan bantuan kepada para pelaku UMKM dengan didasarkan pada permasalahan secara global seperti: menurunnya angka penjualan akibat berkurangnya pelanggan, kesulitan pasokan bahan baku, menurunnya laba yang diperoleh, atau malah menderita kerugian, kesulitan membayar angsuran kredit (gagal bayar), atau tidak berproduksi/tidak berusaha dalam waktu yang lama, dan bertambahnya hutang. Selanjutnya program BAZNAS dalam pengembangan UMKM adalah sedapat mungkin dapat memfasilitasi mereka dalam penjualan produk dan pasokan bahan baku, dengan tetap memperhatikan protokol pencegahan penyebaran Covid-19 dan 
membantu keluarga pelaku UMKM dan pekerja sektor informal yang sama sekali tidak dapat berusaha sehingga mereka kehilangan penghasilan.

Untuk mencapai tujuan diatas dan pentingnya peran BAZNAS dalam membantu pengembangan UMKM maka perlu adanya evaluasi terkait program, pola, pendekatan dan tingkat efektifitas dalam penyaluran dan pendampingan UMKM sesuai dengan tujuan dan sasaran yang jelas. Untuk melihat tingkat kepentingan penelitian ini berikut ditampilkan beberapa penelitian yang membahas tentang peran lembaga ZIS dalam pengembangan UMKM diantaranya adalah:

Pertama, Penelitian yang berjudul Filantropi Kreatif : Pemberdayaan Ekonomi Umat Berbasis Zakat Produktif pada Program 1000 UMKM Lazismu Kabupaten Pekalongan, oleh (Kholidah and Salma, 2020). Penelitian ini menemukan bahwa program 1000 UMKM sangat berperan dalam membantu UMKM yang kesulitan mengembangkan usahanya. Faktor pendukung diantaranya adanya kerjasama dengan lembaga Aisiyah untuk memberikan pendampingan kepada para mustahik.

Kedua, Penelitian yang berjudul Pengelolaan Zakat Produktif Dalam Pengentasan Kemiskinan di Kabupaten Banyumas yang dilakukan oleh (Wahyuningsih and Makhrus, 2019). Hasil penelitian ini menunjukan bahwa program pemberdayaan terdapat peningkatan jumlah pendapatan usaha, stimulan, kesadaran spiritual, dan perubahan paradigma pada mustahik.

Ketiga, Penelitian yang berjudul Zakat Produktif Dan Perannya Terhadap Perkembangan UMKM (Studi pada LAZ el-Zawa UIN Maulana Malik Ibrahim, Malang) yang dilakukan oleh (Miftahul and Ekawaty, 2017). Hasil penelitian adalah pemberian pinjaman modal usaha dengan program qardul hasan UMKM dan mudharabah UMKM. Jumlah zakat produktif yang diterima mustahik berpengaruh signifikan terhadap perkembangan usaha mustahik.

Keempat, Penelitian yang berjudul Analisis Efektivitas Penyaluran Dana Zakat, Infak Dan Sedekah Pada Yayasan Rumah Zakat, oleh (Yudhira, 2020). Berdasarkan hasil penelitian disimpulkan bahwa penyaluran dana (penggunaan asset) pada Yayasan Rumah Zakat dengan menggunakan allocation to collection ratio (ACR) adalah sangat efektif.

Kelima, Penelitian yang berjudul Kinerja Lembaga Zakat Dalam Pemberdayaan Ummat (Studi pada Web Dompet Dhuafa, Lazis NU dan Lazis Muhammadiyah) yang dilakukan oleh (Munadi and Susilayati, 2016). Hasil penelitian menunjukkan bahwa LAZISMU unggul dari sisi kinerja pemanfaatan website dilihat dalam sisi penggunaan empat bahasa dalam website, yaitu: Bahasa Indonesia, Bahasa Arab, Bahasa Inggris, dan Bahasa Francis. LAZISNU telah 
menjabarkan program kerja tidak hanya pada pengelolaan zakat tetapi sampai pada pemberdayaannya.

Keenam, penelitian yang berjudul Analisis Pengelolaan Zakat Produktif Untuk Pemberdayaan Masyarakat (Studi Lapangan Pada Lazismu Kebupaten Jember) oleh (Bashori, 2019). Hasil penelitian ini menunjukkan bahwa manajemen pelaksanaan zakat produktif di LAZISMU sudah cukup baik, meski ada beberapa evaluasi yang harus dilakukan terlebih dari sisi pengawasan dan pembinaan para mustahiq. Kemudian dari sisi pelaksanaan di lapangan, bahwa zakat produktif telah mammpu mendayagunakan masyarakat dari sisi perokonomian. Maka perlu diperluas kembali sasaran dan target para penerima zakat produktif.

Ketujuh, Analisis Efektifitas Pendayagunaan Zakat Produktif Pada Pemberdayaan Mustahik (Studi Kasus LAZISMu Pusat) (Amsari, 2019). Hasil penelitian menunjukkan bahwa ZIS telah efektif dalam pemberdayaan mustahik. Didalam pendayagunaan zakat produktif, LAZISMu selain penyaluranya dilakukan sendiri kemudian juga selalu mengoptimalkan Majelis, Lembaga dan Ortom di lingkungan Muhammadiyah agar berdampak lebih luas penerima manfaatnya dan programnya lebih bervariasi.

Berdasarkan strudi literature yang telah dibahas maka penelitian ini sangat perlu dilakukan karena penelitian ini belum pernah dilakukan pada lembaga BAZNAS di Provinsi Jambi dan ruang lingkup dan fokus penelitian lebih mendasar terkait dengan evaluasi dari program penyaluran bantuan yang meliputi proses awal sampai akhir dengan pendekatan trigulasi sehingga dapat memberikan gambaran riel dampak dari program BAZNAS dalam pemberdayaan UMKM. Serta kedepan dapat dijadikan rujukan dalam penentuan kebijakan dalam pemberdayaan UMKM pada lembaga BAZNAS di masa pandemi.

\section{TINJAUAN PUSTAKA}

\section{Konsep evaluasi}

Evaluasi berasal dari Bahasa inggris yaitu evaluation yang berarti penilaian dan penaksiran (John M, Echols dan Hasan Shadily, 1983). Sementara (Stufflebean, 2001) mendefinisikan evaluasi sebagai the prcess of delineating, obtaining, and providing useful information for judging decision alternatives yang artinya evaluasi merupakan proses menggambarkan, memperoleh, dan menyajikan informasi yang berguna untuk merumuskan suatu elternatif keputusan. Sehinga dapat disimpulkan bahwa evaluasi merupakan kegiatan mengukur atau menilai sesuatu dengan pengekatan kauantitatif dan kualitatif. 


\section{Konsep efektivitas}

Menurut kamus Bahasa inggris efektif berasal dari kata effective yang berarti berhasil atau sesuatu yang dilakukan berhasil dengan baik. Efektivitas merupakan unsur pokok untuk mencapai tujuan dan sasaran yang ditentukanm dalam setiap kegiatan ataupun program. Disebut efektif apabila tujuan atau program tersebut tercapai tujuan atau sasaran yang diinginkannya. Pengertian ini sesuai dengan pendapat H. Emerson dalam (Handayaningrat, 2016) menyatakan bahwa Efektivitas adalah pengukuran dalam arti tercapainya tujuan yang telah ditentukan sebelumnya.

Selanjutnya menurut (Steers, 1986) mengartikan efektivitas sebagai jangkauan usaha suatu program sebagai suatu sistem dengan sumber daya dan sarana tertentu untuk memenuhi tujuan dan sasarannya tanpa melumpuhkan cara dan sumber daya itu serta tanpa memberi tekanan yang tidak wajar terhadap pelaksanaannya. Sementara efektivitas menurut Rifa'i dalam (Yudhira, 2020) diartikan sebagai sebuah keberhasilan suatu aktivitas atau kegiatan dalam mencapai tujuan (sasaran) yang telah ditentukan sebelumnya.

\section{Konsep pemberdayaan UMKM}

Pemberdayaan adalah sebuah proses dan tujuan. Sebagai proses, pemberdayaan adalah serangkaian kegiatan untuk memperkuat keberdayaan kelompok lemah dalam masyarakat, termasuk individu-individu yang mengalami masalah kemiskinan. Sebagai tujuan, maka pemberdayaan menunjukan pada keadaan atau hasil yang ingin dicapai oleh sebuah perubahan sosial; yaitu masyarakat miskin yang berdaya, memiliki mempunyai pengetahuan dan kemampuan dalam memenuhi kebutuhan hidupnya baik yang bersifat fisik, ekonomi, maupun sosial. Menurut Undang-Undang Nomor 20 Tahun 2008 Tentang Usaha Mikro, Kecil, Dan Menengah, Pemberdayaan adalah upaya yang dilakukan Pemerintah, Pemerintah Daerah, Dunia Usaha, dan masyarakat secara sinergis dalam bentuk penumbuhan iklim dan pengembangan usaha. Dengan sasaran pemberdayaan: (1) tercapainya lapangan usaha dan lapangan kerja yang luas; (2) tercapainya peningkatan pendapatan masyarakat; (3) terwujudnya UMKM yang semakin efesien dan mampu berkembang mandiri; (4) terwujudnya pesebaran industri yang merata dan (5) tercapainya peningkatan kemampuan UMKM dalam aspek penyediaan produk jadi, bahan baku baik untuk pasar dalam negeri maupun ekpor. 


\section{Konsep pengelolaan zakat, infak, shadaqah (ZIS)}

Menurut (Budiman, 2011) prinsip GCG (Good Corporate Governance) dapat diterapkan dalam pengelolaan organisasi zakat yang meliputi: Akuntabilitas, transparasi, Responsiveness (Daya Tanggap), keadilan, masalah orientasi, efisiensi dan efektifitas dan rule of syari'at law. Eksistensi Zakat bagi perkembangan ekonomi umat Islam merupakan suatu bagian yang sangat penting karena dengan melalui zakat, mekanisme distribusi kesejahteraan dalam konsep Islam diwujudkan. Pada zakat terjadi perpindahan kekayaan dari yang mampu kepada yang tidak mampu dan berhak menerimanya. Tujuan utama zakat ialah kesejahteraan rakyat. Dalam kutipan al-Quran Surah al-Ma'un dijelaskan, "Tahukah engkau (orang atau kumpulan orang atau negara) yang mendustakan agama”. Jadi negara yang mendustakan agama adalah negara yang tidak sungguh-sungguh mengurusi kaum miskin. Ayat itu menyebutkan, ciri kesalehan suatu pribadi, institusi dan negara adalah pemihakan kepada yang terpinggirkan karena faktor kesalehan akan terganggu jika masalah ekonomi terganggu. Ajaran Islam tidak hanya masalah spiritual tapi juga material (Abdurachman Qadir, 2001).

\section{METODOLOGI}

\section{Teknik dan pengumpulan data}

Teknik penarikan sampel dalam penelitian ini dilakukan dengan menggabungkan antara tehnik purposive sampling dan snowball sampling, dengan tujuan untuk memperoleh hasil yang terbaik. Sedangkan dalam pengumpulan data digunakan metode, observasi, wawancara, dokumentasi dan triguasi.

\section{Jenis dan sumber data}

Penelitian ini menggunakan data primer dan sekunder. Data primer adalah data yang diperoleh langsung dari wawancara atau hasil pengisian kuisioner oleh responden. Data sekunder diperoleh dari laporan hasil penelitian, jurnal, buku artikel dari media cetak, internet dan informasi yang telah tersedia terkait dengan penelitian. Kuisioner yang digunakan dalam penelitian ini menggunakan pertanyaan terstruktur (pertanyaan yang alternatif jawabannya telah tersedia), baik dalam bentuk multiple choice atau skala linkert.

\section{Metode analisis data}

Metode analisis data yang digunakan dalam penelitian ini adalah metode deskriptif kualitatif dan kuantitatif. Analisis deskriptif kualitatif digunakan untuk mendeskripsikan gambaran program BAZNAS dalam pelaksanaan pemberdayaan UMKM di Provinsi Jambi. 
Semantara Analisis deskriptif kuantatif untuk melakukan analisa terkait kinerja dan efektifitas program BAZNAS dalam pelaksanaan pemberdayaan UMKM di Provinsi Jambi.

\section{Objek dan ruang lingkup penelitian}

Objek dari penelitian ini adalah BAZNAS dan para pengusaha UMKM yang menjadi objek penyaluran bantuan program pemberdayaan yang di salurkan oleh BAZNAS. Sementara ruang lingkup penelitian di lakukan pada BAZNAS dan UMKM yang berdomisili di Provinsi Jambi.

\section{Alat analisis data}

Alat analisis yang digunakan untuk masalah pertama yaitu gambaran program BAZNAS dalam pemberdayaan UMKM menggunakan analisis deskriptif kualitatif.

Selanjutnya untuk menjawab tingkat efektivitas program BAZNAS dalam pemberdayaan UMKM digunakan menggunakan Zakat Core Principles (ZCP). Model ini bertujuan untuk mengetahui bagaimana penyaluran dana zakat yang dikelola lembaga zakat telah memenuhi standar kriteria efektif sesuai dengan acuannya sehingga pengelolaannya dapat dipertanggung jawabkan. Berdasarkan model ini, maka rasio yang digunakan adalah Allocation to Collection Ratio (ACR). Rasio ini digunakan untuk mengukur kemampuan sebuah lembaga zakat dalam menyalurkan dana zakatnya dengan cara membagi total dana penyaluran dengan total dana penghimpunan. Indikator penilaian pada model ini terdiri dari beberapa kategori diantaranya: Highly Effective (jika ACR $\geq 90$ persen), Effective (jika ACR mencapai 70-89 persen), Fairly Effective (jika ACR mencapai 50-69 persen), Below Expectation (jika ACR mencapai 20-49 persen), dan Ineffective (jika ACR $<20$ persen).

Dan untuk menjawab masalah ketiga yaitu strategi kebijakan dalam pemberdayaan UMKM digunakan model analisis SWOT. Analisa SWOT tersebut digunakan untuk mengembangkan suatu solusi dari permasalahan yang ada yang didasarkan pada Strength (S), Weakness (W), Opportunities (O), dan Threats (T) yang artinya kekuatan, kelemahan, peluang dan ancaman atau kendala secara sistematis yang dihadapi dalam keberlangsungan UMKM tersebut. 


\section{HASIL}

\section{Program Badan Amil Zakat Nasional (BAZNAS) Provinsi Jambi di masa pandemi covid} 19

BAZNAS sesuai amanat undang-undang diamanatkan untuk bisa bersama-sama pemerintah mengentaskan kemiskinan dan meningkatkan kesejahteraan rakyat. BAZNAS merasa ikut bertanggung jawab untuk bersama-sama pemerintah menyelesaikan persoalanpersoalan khususnya di masa pandemic covid 19 ini. Maka dari itu BAZNAS membuat satgas covid 19 yang mempunyai beberapa program yaitu :

1. Program "Kita Jaga Usaha” dengan cara membantu UMKM terdampak covid 19. Iniasi Program Kita Jaga Usaha berupa :

- Program UMKM Bangkit melalui pemberian bantuan langsung kepada UMKM di wilayah PPKM level 3 dan level 4 dengan jumlah bantuan sebesar Rp 1.000.000,yang diberikan melalui kartu ATM di Bank Syariah Indonesia (BSI)

- Program Dapur kuliner Nusantara yaitu program pemberdayaan warteg, warung nasi, warung padang dan usaha kuliner skala kecil lainnya untuk menyediakan paket makanan yang akan didistribusikan kepada pelaku isoman, panti asuhan, panti jompo, lembaga permasyarajatan, pesantren, rumah singgah, nakes, dan warga terdampak PPKM.

2. Program "Kita Jaga Kyai" sebagai upaya membantu pemerintah dalam menanggulangi pandemic covid 19 khususnya di lingkungan pondok pesantren. Banyaknya ulama yang wafat menjadi alah satu pendorong diluncurkannya program ini yang terdiri dari dukungan vaksinasi, paket imunitas, paket higienitas, medical check up dan dukungan isoman

3. Program "Kita Jaga Yatim" sebagai bentuk kepedulian melihat fenomena banyaknya anakanak harus kehilangan orangtuanya akibat terpapar covid 19. Melalui kita jaga yatim BAZNAS berkomitmen memastikan keberlangsungan hidup para keluarga rentan, termasuk akses pendidikan layak, sehingga anak-anak yatim yang kehilangan orangtua akibat virus covid 19 tetap bisa mendapatkan hak pendidikan mereka

Selain itu BAZNAS telah berperan dan berkontribusi aktif dalam upaya penanggulangan covid 19 di Indonesia melalui berbagai program darurat dan program recovery dalam membantu sisi perekonomian masyarakat yang terdampak. Program darurat tersebut diantaranya Bantuan Paket Penggali Kubur, Bantuan Paket Pemulasaran Jenazah 
Untuk Penyintas Covid 19, Bantuan Pemulasaran Jenazah Isolasi Mandiri, Bantuan Paket Imun bagi Nakes, dan lain sebagainya

Efektivitas program BAZNAS dalam pemberdayaan UMKM pada masa covid-19 di Provinsi Jambi

Berdasarkan data yang dikeluarkan oleh BAZNAS Provinsi Jambi, pada tahun 2021, penghimpunan ZIS oleh BAZNAS mengalami fluktuasi. Sepanjang tahun 2021 ini, penghimpunan ZIS terbesar terjadi di bulan mei 2021 yaitu sebesar Rp 406 juta dan yang terkecil terjadi di bulan januari yaitu sebesar Rp 201 juta. Sementara untuk penyaluran ZIS, terbesar terjadi di bulan april 20021 yaitu sebesar 504 juta dan yang terkecil terjadi di bulan januari yaitu 22 juta.

Tabel 1

Data penghimpunan dan penyaluran zakat, infak dan shadaqah di BAZNAS Provinsi Jambi Tahun 2021

\begin{tabular}{|c|c|r|c|r|c|}
\hline No & Bulan & Penghimpunan & \multicolumn{1}{c|}{$\%$} & \multicolumn{1}{c|}{ Penyaluran } & $\%$ \\
\hline 1 & Januari & $201.735 .521,00$ & - & $22.258 .000,00$ & - \\
\hline 2 & Februari & $230.780 .091,46$ & 14,40 & $460.691 .200,00$ & 1969,78 \\
\hline 3 & Maret & $261.458 .931,50$ & 13,29 & $382.452 .600,00$ & $-16,98$ \\
\hline 4 & April & $401.456 .596,47$ & 53,54 & $504.550 .000,00$ & 31,92 \\
\hline 5 & Mei & $406.025 .578,00$ & 1,14 & $279.842 .000,00$ & $-44,54$ \\
\hline 6 & Juni & $222.107 .057,50$ & $-45,30$ & $94.600 .000,00$ & $-66,20$ \\
\hline 7 & Juli & $345.116 .520,50$ & 55,38 & $262.477 .000,00$ & 177,46 \\
\hline & Total & $2.068 .680 .296,43$ & - & $2.006 .870 .800,00$ & - \\
\hline
\end{tabular}

Sumber : Baznas Provinsi Jambi, 2021

\section{Grafik 1}

Perkembangan perhimpunan dan penyaluran zakat, infak dan shadaqah di BAZNAS Provinsi Jambi Tahun 2021

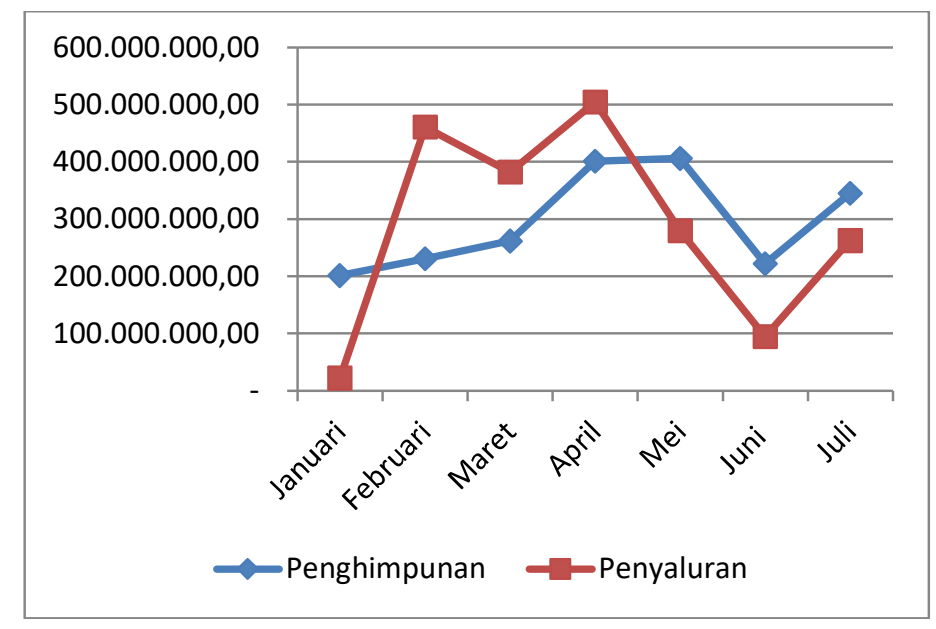

Dari Tabel 1 terlihat bahwa perhimpunan dan penyaluran ZIS mengalami flustuasi yang 
cukuo tajam mulai bulan januari sampai juli 2021. Pada bulan april 2021, ZIS yang terhimpun mencapai Rp 401 jutaan meningkat cukup tajam dibanding bulan sebelumnya yaitu sebesar Rp 261 jutaan, namun kembali menurun sebesar 45\% pada bulan juni dibadingkan dengan bulan mei 2021. Di sisi lain, penyaluran ZIS pada bulan januari 2021 hanya diangka $R p 22$ jutaan dan meningkat tajam sebesar $1.196 \%$ menjadi Rp 460 jutaan di bulan februari 2021. Namun pada bulan maret, mei dan mengalami penurunan masing-masing sebesar $16 \%, 44 \%$ dan $66 \%$ dibandingkan dengan bulan-bulan sebelumnya.

Sementara itu jika melihat efektifitas pelaksanaan program BAZNAS dimana rasio yang digunakan adalah Allocation to Collection Ratio (ACR) dengan cara membagi total dana penyaluran dengan total dana penghimpunan. Indikator penilaian pada model ini terdiri dari beberapa kategori diantaranya: Highly Effective (jika ACR $\geq 90$ persen), Effective (jika ACR mencapai 70-89 persen), Fairly Effective (jika ACR mencapai 50-69 persen), Below Expectation (jika ACR mencapai 20-49 persen), dan Ineffective (jika ACR $<20$ persen).

Tabel 2

Efektifitas program BAZNAS Provinsi Jambi tahun 2021

\begin{tabular}{|c|c|c|c|c|c|}
\hline No & Bulan & Penghimpunan & Penyaluran & Efektifitas & Kategori \\
\hline 1 & Januari & $201.735 .521,00$ & $22.258 .000,00$ & 11,03 & Inefective \\
\hline 2 & Februari & $230.780 .091,46$ & $460.691 .200,00$ & 199,62 & Higly efective \\
\hline 3 & Maret & $261.458 .931,50$ & $382.452 .600,00$ & 146,28 & Higly effective \\
\hline 4 & April & $401.456 .596,47$ & $504.550 .000,00$ & 125,68 & Higly effective \\
\hline 5 & Mei & $406.025 .578,00$ & $279.842 .000,00$ & 68,92 & Fairy Effective \\
\hline 6 & Juni & $222.107 .057,50$ & $94.600 .000,00$ & 42,59 & Below expectation \\
\hline 7 & Juli & $345.116 .520,50$ & $262.477 .000,00$ & 76,05 & effective \\
\hline & Total & $\begin{array}{c}2.068 .680 .296,4 \\
3\end{array}$ & $2.006 .870 .800,00$ & 97,01 & Higly efective \\
\hline
\end{tabular}

Sumber : Data diolah, 2021

Jika dilihat dari Tabel 2, efektifitas program BAZNAS mengalami fluktuasi dimana efektifitas tertinggi terjadi di bualn februari yaitu sebesar 199,62 sementara efektifitas terrendah terjadi dibulan sebelumnya yaitu bulan januari sbesar 11,03. Jika dilihar dari bulan januari s.d juli 2021, efektifitas program BAZNAS : 1 kali berada dalam kategori ineffective, 1 kali berada dalam kategori below expectation, 1 kali berada dalam kategori fairy effective, 1 kali berada dalam kategori effective dan 3 kali berada dalam kategori haigly effective. Dan jika dirata-ratakan, selama 7 bulan ini program BAZNAS berada dalam kategori higly effective. 


\section{Grafik 2}

Efektifitas perhimpunan dan penyaluran zakat, infak dan shadaqah di BAZNAS

Provinsi Jambi Tahun 2021

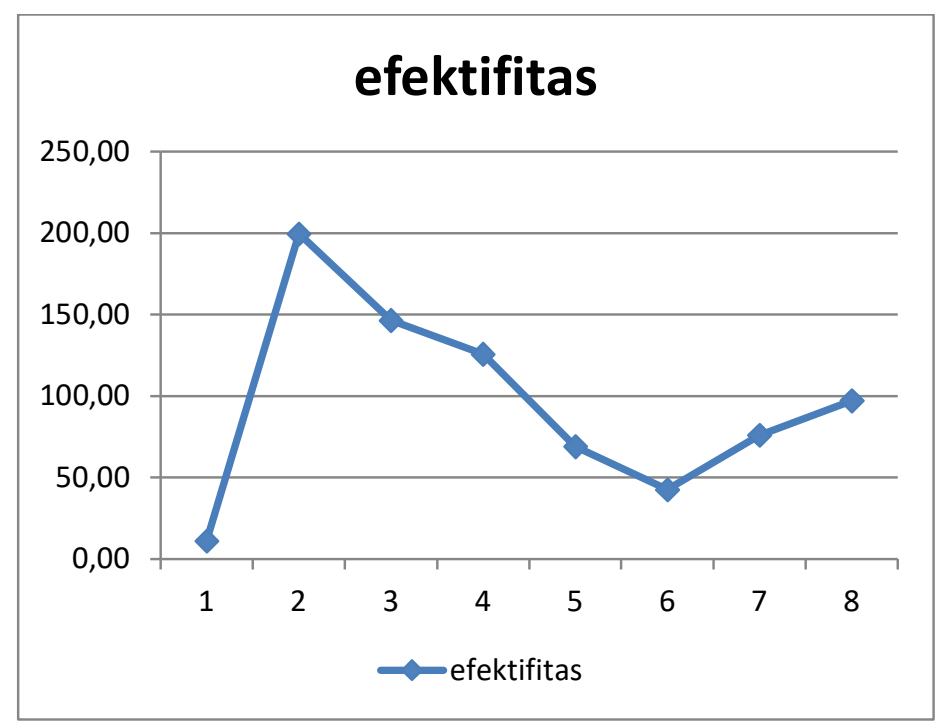

Strategi dalam pemberdayaan UMKM pada masa covid-19 di Provinsi Jambi

Untuk mengetahui strategi yang tepat digunakan untuk memberdayakan UMKM yang terkena dampak pandemic covid 19 maka menggunakan analisis SWOT agar strategi yang diambil turut mempertimbangkan kondisi kekuatan, kelemahan, peluang dan ancaman UMKM yang ada di Provinsi Jambi. 


\section{Tabel 3}

\section{SWOT pemberdayaan UMKM di Provinsi Jami}

\begin{tabular}{|c|c|c|}
\hline INTERNAL & Strenght (S) & Weaknesses (W) \\
\hline EKSTERNAL & $\begin{array}{l}\text { 1. Modal yang relative } \\
\text { kecil karena harga } \\
\text { produk } \text { UMKM } \\
\text { cenderung rendah } \\
\text { sehingga mudah pula } \\
\text { untuk menjual produk } \\
\text { UMKM. } \\
\text { 2. Mudah mendapatkan } \\
\text { tenaga kerja dan rata- } \\
\text { rata tenaga kerja } \\
\text { bersedia diberikan upah } \\
\text { rendah ararena } \\
\text { rendahnya tingkat } \\
\text { pendidikan tenaga kerja } \\
\text { 3. Mudah berpindah lokasi } \\
\text { usaha dan promosi } \\
\text { dapat dilakukan dari } \\
\text { mulut ke mulut }\end{array}$ & $\begin{array}{l}\text { 1. Kesulitan mengembangkan usaha } \\
\text { karena terkendala modal. Hal ini } \\
\text { terjadi karena omset usaha kecil dan } \\
\text { kesulitan dalam mengelola keuangan } \\
\text { usaha } \\
\text { 2. Tenaga kerja tidak terampil dan } \\
\text { gampang keluar masuk. } \\
\text { 3. Sulit mendapatkan konsumen yang } \\
\text { loyal karena lokasi usaha yang sering } \\
\text { berpindah dan persaingan usaha } \\
\text { yang tinggi karena usaha mudah } \\
\text { ditiru. }\end{array}$ \\
\hline Opportunities (O) & Strategi SO & gi WO \\
\hline 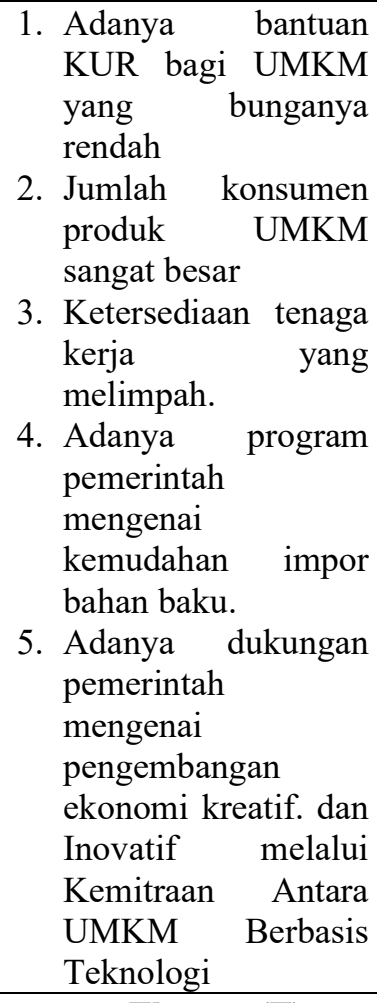 & $\begin{array}{l}\text { 1. Bekerjasama dengan e- } \\
\text { commerce platform } \\
\text { dalam menyalurkan } \\
\text { kredit ke UMKM dengan } \\
\text { skema chanelling. } \\
\text { 2. Melakukan perbaikan } \\
\text { system pendidikan } \\
\text { formal dan kualitas } \\
\text { lulusan agar disesuaikan } \\
\text { dengan pasar kerja. } \\
\text { 3. Memperbaiki system } \\
\text { OSS agar UMKM mudah } \\
\text { membuat perijinan } \\
\text { 4. Mendukung gerakan } \\
\text { \#Bangga buatan } \\
\text { Indonesia. }\end{array}$ & $\begin{array}{l}\text { 1.Pemerintah harus memfasilitasi agar } \\
\text { UMKM yang unbankable menjadi } \\
\text { bankable. } \\
\text { 2. Meningkatkan kesadaran masyarakat } \\
\text { untuk membeli produk lokal. } \\
\text { 3.Meningkatkan kualitas pelaku } \\
\text { UMKM melalui pemberian pelatihan } \\
\text { berbasis kompetensi } \\
\text { 4.Memastikan kesediaan bahan baku } \\
\text { bagi UMKM. } \\
\text { 5.Membuat kawasan khusus UMKM }\end{array}$ \\
\hline Threats (T) & Strategi ST & Strategi WT \\
\hline $\begin{array}{lr}\text { 1. Penilaian } & \text { Perbankan } \\
\text { terhadap } & \text { UMKM } \\
\end{array}$ & $\begin{array}{l}\text { 1. Meningkatkan } \\
\text { beli masyarakat }\end{array}$ & $\begin{array}{lll}\text { 1. Mendukung } & \text { kebijakan BI yang } \\
\text { mewajibkan } & \text { Bank Umum untuk }\end{array}$ \\
\hline
\end{tabular}




\begin{tabular}{|c|c|c|}
\hline $\begin{array}{l}\text { yang dianggap } \\
\text { Unbankable. } \\
\text { 2. Kurangnya perhatian } \\
\text { pemerintah } \\
\text { meningkatkan } \\
\text { kualitas tenaga kerja } \\
\text { 3. Ketidaksediaan } \\
\text { bahan baku } \\
\text { 4. Adanya liberalisasi } \\
\text { perdagangan. } \\
\text { 5. Berlakunya } \\
\text { liberalisasi } \\
\text { perdagangan }\end{array}$ & 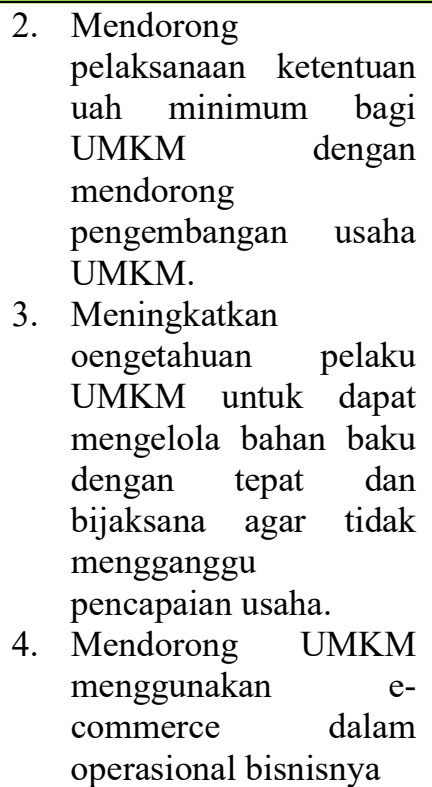 & $\begin{array}{l}\text { menyalurkan 20\% kredit ke UMKM } \\
\text { dari total kredit. } \\
\text { 2. Meningkatan peran UMKM dalam } \\
\text { pengentasan pengangguran melalui } \\
\text { pemberdayaan UMKM. } \\
\text { 3. Mendorong UMKM melakukan } \\
\text { efisiensi usaha dalam mengatasi } \\
\text { harga bahan baku yang berfluktuasi. } \\
\text { 4. Mempersiapkan UMKM agar dapat } \\
\text { berdaya saing di era perdagangan } \\
\text { bebas. }\end{array}$ \\
\hline
\end{tabular}

\section{KESIMPULAN DAN SARAN}

\section{Kesimpulan}

Program-Program yang diluncurkan BAZNAS pada masa Pandemi COvid 19 adalah Program “Kita Jaga Usaha”, Program “Kita Jaga Kyai”, Program “Kita Jaga Yatim”. Selain itu BAZNAS telah berperan dan berkontribusi aktif dalam upaya penanggulangan covid 19 di Indonesia melalui berbagai program darurat dan program recovery dalam membantu sisi perekonomian masyarakat yang terdampak.

Efektifitas program BAZNAS mengalami fluktuasi dimana efektifitas tertinggi terjadi di bualn februari yaitu sebesar 199,62 sementara efektifitas terrendah terjadi dibulan sebelumnya yaitu bulan januari sebesar 11,03. Jika dilihar dari bulan januari s.d juli 2021, efektifitas program BAZNAS : 1 kali berada dalam kategori ineffective, 1 kali berada dalam kategori below expectation, 1 kali berada dalam kategori fairy effective, 1 kali berada dalam kategori effective dan 3 kali berada dalam kategori haigly effective. Dan jika dirata-ratakan, selama 7 bulan ini program BAZNAS berada dalam kategori higly effective.

Untuk strategi yang tepat digunakan untuk memberdayakan UMKM yang terkena dampak pandemic covid 19 maka menggunakan analisis SWOT dimana aspek yang dilihat adalah aspek permodalan, aspek tenaga kerja dan aspek pemasaran. 


\section{SARAN}

Menyeimbangkan antara penghimpunan dan penyaluran ZIS setiap bulan agar efektifitas program BAZNAS terjaga setiap bulannya

Strategi BAZNAS Provinsi Jambi dalam peningkatan jumlah muzakki masih belum maksimal dan jauh dari kesempurnaan. Untuk itu perlu ada penelitian lanjutan terhadap masalah-masalah lainnya yang belum disinggung untuk kemudian dikembangkan oleh peneliti selanjutnya.

\section{DAFTAR PUSTAKA}

Amsari, S. (2019) 'Analisis Efektifitas Pendayagunaan Zakat Produktif pada Pemberdayaan Mustahik (Studi Kasus Lazizmu Pusat)', Aghniya Jurnal Ekonomi Islam, 1(2), pp. 321-345.

Bashori, D. C. (2019) 'Analisis Pengelolaan Zakat produktif Untuk Pemberdayaan Masyarakt (Studi Lapangan Pada Lazizmu Kabupaten Jember)', At-Tasharruf: Jurnal Kajian dan Bisnis Syariah, 1(1), pp. 1-9.

Budiman, A. A. (2011) 'Akuntabilitas Lembaga Pengelola Wakaf', Walisongo: Jurnal Penelitian Sosial Keagamaan, 19(1), p. 75.

Handayaningrat, S. (1995). Pengantar Studi Ilmu Administrasi dan Manajemen.Toko Gunung Agung, Jakarta.

John, M. E. and Hassan, S. (1992). Kamus Indonesia Inggris. Gramedia, Jakarta.

Kholidah, N. and Salma, A. N. (2020) 'Filantropi Kreatif: Pemberdayaan Ekonomi Umat Berbasis Zakat Produktif pada Program 1000 UMKM Lazismu Kabupaten Pekalongan', Cakrawala: Jurnal Studi Islam, 14(2), pp. 93-101.

Miftahul, K. and Ekawaty, M. (2017) 'Zakat Produktif dan Perannya Terhadap Perkembangan UMKM (Studi pada LAZ el-Zawa UIN Maulana Malik Ibrahim, Malang)', in Proceeding peluang dan tantangan pengembangan UMKM dan ekonomi kreatif dalam era global dan digital.

Munadi, M. and Susilayati, M. (2016) 'Kinerj Lembaga Zakat Dalam Pemberdayaan Umat (Studi pada Web Dompet Dhuafa, Lazis NU dan Lazis Muhammadiyah)', Inferensi, Jurnal Penelitian Sosial Keagamaan, 10(2), pp. 289-308.

Steers, R. M. (1986). Efektivitas Organisasi. Erlangga, Jakarta.

Stufflebean, D. L. (2001) 'Evaluation Models', in New Directions for Evaluation, pp. 1-92.

Wahyuningsih, S. and Makhrus, M. (2019) 'Pengelolaan Zakat Produktif dalam Pengentasan Kemiskinan di Kabupaten Banyumas’, Jurnal Hukum Ekonomi Syariah, 2(2), p. 179.

Yudhira, A. (2020) 'Analisis Efektivitas Penyaluran Dana Zakat, Infak dan sedekah Pada Yayasan Rumah zakat', Jurnal ilmiah akutansi keuangan dan bisnis, 1(1), pp. 1-15. 